\title{
Multiple Intelligences and English Writing Proficiency Levels among Malaysian Pre-university Students with Rural and Urban Socio-economic Backgrounds: A Comparative Study
}

\author{
Iziana Hani Ismail ${ }^{1}$, Asmaa AISaqqaf ${ }^{2, *}$, Wardatul Akmam Din ${ }^{1}$ \\ ${ }^{1}$ Preparatory Centre of Science and Technology, Universiti Malaysia Sabah, Kota Kinabalu, 88400, Malaysia \\ ${ }^{2}$ Faculty of Psychology and Education, Universiti Malaysia Sabah, Kota Kinabalu, 88400, Malaysia
}

Received September 2, 2020; Revised October 24, 2020; Accepted November 11, 2020

\section{Cite This Paper in the following Citation Styles}

(a): [1] Iziana Hani Ismail, Asmaa AlSaqqaf, Wardatul Akmam Din, "Multiple Intelligences and English Writing Proficiency Levels among Malaysian Pre-university Students with Rural and Urban Socio-economic Backgrounds: A Comparative Study," Universal Journal of Educational Research, Vol. 8, No. 12, pp. 6737 - 6744, 2020. DOI: 10.13189/ujer.2020.081238.

(b): Iziana Hani Ismail, Asmaa AlSaqqaf, Wardatul Akmam Din (2020). Multiple Intelligences and English Writing Proficiency Levels among Malaysian Pre-university Students with Rural and Urban Socio-economic Backgrounds: A Comparative Study. Universal Journal of Educational Research, 8(12), 6737 - 6744. DOI: 10.13189/ujer.2020.081238.

Copyright $\mathrm{C} 2020$ by authors, all rights reserved. Authors agree that this article remains permanently open access under the terms of the Creative Commons Attribution License 4.0 International License

\begin{abstract}
The disparity of the English language performance between the Malaysian rural and urban students remains a crucial issue, yet much is to be known about factors that actually influence the students' English proficiency across levels, especially those who live outside the cities. The objectives of this paper are to identify the Multiple Intelligence profiles and the significant intelligence of the urban and rural pre-university students at a public university in Malaysia, and to investigate whether there is any difference in the English writing test scores between the two groups. A demographic questionnaire, Multiple Intelligence Profiling Questionnaire (MIPQ III) and a Paper 800/4 (Writing) Question 2 of Malaysian University English Test (MUET) March 2016 question were used in this study. Sixty pre-university students were purposively selected for the current research from Preparatory Centre of Science and Technology, Universiti Malaysia Sabah, Malaysia. The data were collected and analyzed using the Independent Sample t-test. Results suggest that there is a statistically significant difference in the mean scores of Interpersonal, Environmental, and Visual-Spatial intelligences between the urban and rural pre-university students. Unexpectedly, the findings show that the urban students display higher
\end{abstract}

Environmental intelligence compared to the rural group. Additionally, a significant difference is also identified between urban and rural students in their writing scores, as the results show that the urban students performed better in the writing tests than the students in the rural areas. This study calls Malaysian English educators to acknowledge students' differences in learning, thus creating a conducive classroom experience and redesigning the lessons by incorporating all intelligences for the students to actively manifest their preferred learning styles in acquiring English language. Future research would include more language skills to be examined in a bigger number of students.

Keywords English Proficiency, Urban, Rural, Multiple Intelligences, Pre-university Students, University Malaysia Sabah, Malaysia

\section{Introduction}

The National Education Blueprint (2013-2025) aspires to raise the standards of Malaysia's education system by 
improving its quality to basic education, including developing cognitive skills [18]. Many initiatives have been rolled out to transform the education system in fostering the development of the whole children so that all students, particularly those from underserved populations, can thrive. Malaysia clearly aims to improve its educational system by constantly implementing educational policy reforms; however, this transformation seems ineffective in enhancing English language acquisition of most Malaysian students, particularly those staying in rural areas [23]. In a society where quality of English-language schools is highly commercialized, access to them is no doubt in the hand of rich. In contrast to urban cities and towns where English is robustly promoted, it is difficult to experience similar learning opportunities or gain access even the most basic English-language education in underdeveloped rural areas [2].

To date, English teaching and learning has been an extremely heated topic in Malaysia, with national policy-makers and public hotly debating whether to make it compulsory for the students to pass the English language subject paper in Sijil Pelajaran Malaysia (SPM) from 2016. This broad vision seems impractical to be implemented because most of the Malaysian students are constantly being challenged with poor English acquisition despite years of learning it in schools. It was also a challenge for teachers in Malaysian schools to bridge the gap of English proficiency between the urban and rural students. The Malaysian Examination Board revealed an almost consistent failure rate for English in Sijil Pelajaran Malaysia (SPM) (i.e., Malaysian Certificate of Education) since 2011. Almost a quarter of the 450,000 SPM candidates failed this subject from 2011 to 2014, forcing the top-down policy makers to postpone the decision in making English a compulsory subject in the examination due to this worrying trend. In the 2013, English Lab under Government Transformation Program conducted by the Performance Management and Delivery Unit (PEMANDU) of the Prime Minister's Department conclusively proved that English was the students' weakest core subject in national assessments, where $25 \%$ of candidates failed at Ujian Pencapaian Sekolah Rendah (UPSR) or Primary School Achievement Test, $23 \%$ at Penilaian Menengah Rendah (PMR) (now called Form Three Assessment -PT3), and 22\% at SPM of the same year. The same report highlighted that Malaysian students performed poorly in international English examinations with $50 \%$ of candidates the English 1119 paper (written paper) in 2013. To add to this worrying trend, $62 \%$ of the Malaysian University English Test (MUET) examination candidates achieved only Bands 1 and 2 from 2011 to 2014, placing them under the categories of 'limited user' and 'very limited user' of English. This inability to use the language effectively is manifested by the fact that 48 percent of employers rejected students due to poor English [15].
This scenario is especially worsened in rural areas. Teaching English in Malaysian rural schools has always been a challenge for educators as the struggle to pull proficiency levels up against a backdrop where English is viewed as the foreign language as the language is almost non-existent anywhere other than the few periods of English per week for learners [3]. Sabah Education Director, Mistirine Radin pointed out that Sabah education sector currently deals with the issue of lacking qualified and trained English teachers in the rural areas [9]. Also, lack of exposure to the English language as well as the insufficient practice of the language itself has caused these students to fail to see the need to use English in the daily lives [23].

Based on the report generated by Malaysian Examination Syndicate, Ministry of Education Malaysia in 2008, a much higher percentage of Grade D and E in English for Lower Secondary Examination (PMR) was recorded among candidates from the rural areas compared to the ones in urban from 2006 to 2008. The Malaysian Certificate of Education (SPM) candidates also denoted the same trend as the report shows more candidates landed themselves in Grades 7D, 8E, and 9G [8]. Although the urban-rural achievement gap appears to be narrowed, but this worrying trend has forced The National Union of Teaching Profession (NUTP) to call Education Ministry to conduct a comprehensive study into the decline in English proficiency among students [13]. Majority of the students in the urban schools are better off than rural areas in English language performance in national examinations, with most of the students frequently show impressive language acquisition, as per the fact that the urban students are immersed with an all-English environment lifestyle and many of them have been brought up by affluent groups in society homes where English is their home language [3]. Rural students, however, often view English as a foreign language because they hardly have any opportunity to practice it outside the classrooms. Their parents or peers are not proficient enough to give them necessary educational support and their families' socio-economic status does not grant them any easy access to books, CD's, or even television in some cases [3]. The huge academic achievement gap between the urban and rural students indicates that the students may have different levels of English proficiency, and further highlights the disparity in the urban-rural divide.

As we enter the new education era, differentiation in classroom instructions has become enormously important in the process of teaching and learning in the classrooms [12]. Yet, many teachers fail to acknowledge the students' differences and restrict themselves to teaching students with only one-size-fit-all approach. This is probably due to the educational settings still favor those who are linguistically and mathematically-inclined because these values are highly valued in the culture [1]. Since the culture puts heavy emphasis on these two skills, teachers 
tend to modify the teaching strategies and instructions to serve Verbal-Linguistic and Logical-Mathematical intelligences while the other intelligences are not given proper attention or taken seriously within the educational system [4]. Failure to acknowledge the students' differences in learning would end up making them lose interest in learning English and eventually affect the students' proficiency levels [23].

The unchanged medium of instructions in the classrooms may partly contribute to the gradual decline in the standard of English in Malaysia, especially in the state of Sabah, where 1191 secondary schools were identified with SPM English failure rates exceeding $23 \%$ based on the statistics reported by PEMANDU in 2013. This further explains why some of the learners fail to grasp and master English language even though they have learned the language skills: reading, writing, speaking, and listening throughout years of schooling. The poor performance continues from one level to the next in schools and comes to a head at the tertiary level. The problems can become more intense at the tertiary level where students are expected to write with more maturity and sophistication to match their perceived level of intellect [7]. Eleven years of learning English language are not much of a help to attain reasonable English literacy among majority Malaysia students [23].

Given this landscape, educators need to be aware that every learner has different potentials and abilities in acquiring new knowledge. Through Multiple Intelligence (MI) Profiles, educators can identify the learners' significant domain, thus appreciate students' differences in learning by acknowledging and planning out lessons that tap on every learner's strengths and compensate their areas of weakness while learning using MI [22]. Educators would become more creative in presenting information in various ways to accommodate all nine intelligences to enhance learning in the classroom and expand their repertoire of techniques, tools, and strategies beyond the typical linguistic and mathematical once predominantly used in classrooms [10]. It is important for educators to be aware and nurture all of the different human intelligences and their combinations so that they could offer children more opportunities for success as educators make the learning situation more meaningful for them [22].

Although there have been numerous studies keenly interested in studying the cause-and-effect relationship between the Multiple Intelligences and language skills development, only a few were conducted to investigate the effectiveness of this theory towards the pre-university students. Moreover, it is believed that there are limited studies done concerning the implementation of Multiple Intelligences within the Malaysian educational context, as most of the past research studies were conducted in international settings. So, this study attempts to extent our knowledge in terms of the application of Multiple
Intelligences Instructions and Strategies within the Malaysian educational setting and pre-university students as its target population, as to fill in the gap of area that is under-explored by many.

In addition, most of the research studies tended to focus on the gender divide in English language performance than the impact of socioeconomic status on the students' academic achievement. Lack of research studies concerning the students' socio-economic backgrounds has triggered this study to be conducted, particularly in higher learning institutions. Thus, this study aims to identify the urban and rural pre-university students' Multiple Intelligence Profiles, and also look at the differences in English proficiency levels between urban and rural pre-university students, and highlight the disparity between them. It is crucial for the educators to understand the concept of Multiple Intelligences, as it will not only diversify teachers' teaching strategies in classrooms, but it also provides a foundation in understanding which approaches students learn the best. This study also aspires to bridge the gap in English proficiency between rural and urban schools, by driving more in-depth studies or projects to increase the students' accessibility in resources and create more opportunities for them to improve their English through Multiple Intelligences. This theory acts as a bridge for the teachers to understand the idea of intelligences, and acknowledge the students' differences in learning by developing interactive and interesting classroom activities in which they learn best.

The main purpose of this study is therefore to determine whether the urban students outperform the rural peers in the writing test. Thus, this study is guided by the following research objectives:

1. To identify the predominant intelligence of the urban and rural pre-university students at a public university in Malaysia.

2. To analyse the disparity of English writing performance between the urban and rural pre-university students at a public university in Malaysia.

\section{Materials and Methods}

\subsection{Research Design}

This study displays some characteristics of the quantitative research, which are (i) analyzing trends, (ii) comparing groups, or (iii) relating variables using statistical analysis. The most important variables; the dependent and independent variables need to be considered in this cause-and-effect relationship. A dependent variable can be measured using continuous or categorical scores. In this study, the dependent variable is the achievement scores on the writing test of the two groups; urban and rural, thus reflecting the proficiency 
levels among these students. An independent variable, however, is an attribute or a characteristic that influences or affects an outcome or dependent variable. With specific regard to this study, the independent variable is measured by categorizing the students into rural and urban. This study mainly tries to compare the achievement between the urban and rural pre-university students through the writing scores, thus trying to find out the urban students perform better in the writing test in comparison with the students from the rural areas.

\subsection{Sample Selection}

This study investigates the achievement in the writing exam among Malaysian pre-university students with different socio-economic backgrounds. Sixty pre-university students from Preparatory Centre of Science and Technology, Universiti Malaysia Sabah, Malaysia, participated in this study. Those students were from ten states of Peninsular Malaysia; Kedah, Johor, Melaka, Pahang, Pulau Pinang, Selangor, Federal Territory of Kuala Lumpur, Kelantan, Negeri Sembilan, Perak, and three states from East Malaysia; Sabah, Sarawak, and Federal Territory of Labuan.

The students' backgrounds were regarded as rural and urban based on the population of the districts of the states which they reside in. Students with rural socio-economic background were determined through the population of the district of under 10,000 people, whereas for urban, the population was more than 10,000 people [19]. The researchers deemed locations as rural and urban by logging in the students' information in Population and Housing Census of Malaysia 2020 database at https://ecensus.mycensus.gov.my/landing. It serves as a gateway to web-based geostatistics information to search, access, and view comprehensive and detailed information or profiles of Malaysian population and housing for demographic and socio-economic characteristic of the population. Through the Census, it portrays the actual Malaysia's population and serves as a source of reference and basis for the country's future planning and development.

In general, none of the respondents participated in this study scored grade D and below for English subject in SPM. Only one respondent scored B, which recorded the lowest proportion at two percent of the sample population. Over half of the those surveyed scored A for the English subject in the exam with 45 percent in total and less than a fourth of those scored $\mathrm{A}+$ at 22 percent. $\mathrm{A}-$ and $\mathrm{B}+$ recorded almost the same percentage at 11 and 12 percent respectively, while $\mathrm{C}+$ and $\mathrm{C}$ were among the lowest number of grades scored by these students at five and three percent respectively. This datum confirms that the students generally have good English proficiencies as almost 80 percent of them belonged to Distinction grades (A-, A, and $\mathrm{A}+$ ), thus the selection threat of this study is controlled. All of the participants were aged between 17 and 18 at the beginning of the study. Criteria for selecting the subjects were as follows:

a). Pre-university students studying at the Preparatory Centre of Science and Technology

b). Enrolled in UB0013 The Foundation of English I course

\subsection{Research Instruments and Data Collection Procedures}

The main aim of this study is to investigate the disparity of the English language achievement among the urban and rural students. The performance measure (MUET Writing question) was used to determine achievements through scores displayed in the writing test by the two groups of students. This study also provides a statistical analysis to examine if the disparity of the achievement between the two groups of students were substantial. The following instruments were used for the data collection:

a). Part A: A demographic questionnaire

b). Part B: The Multiple Intelligence Profiling Questionnaire III (MIPQIII)

c). Writing Paper 800/4 (Writing) Question 2 of Malaysian University English Test (MUET) March 2016

\subsubsection{Research Procedures}

Prior to administering the research instruments, 60 pre-university students were briefed on the purpose of this research. An informed consent form for participants was developed and signed before they participated in this study, even this research posed minimal risk to the participants. They were informed about the research and were given choices which allow them to agree or decline from participating in it. The students' agreement to participate in this study was obtained only after a thorough explanation of the research process.

Only then, each of the student received a set of questionnaires consisting two parts; $\mathrm{A}$ and $\mathrm{B}$ which identify the students' (i) demographic background and (ii) predominant intelligence through Multiple Intelligences Profiling Questionnaire III (MIPQ III). This questionnaire roughly took 20 to 30 minutes to be completed. It was then continued with the writing test. It was administered to the students soon after they had completed answering the questionnaire. The students were tested to produce a full essay on argumentative genre in 50 minutes. This task requires the students to give an opinion or make a stand based on the statement given. Logic, depth, and maturity of thought on whether the traditional make role has remained unchanged with modernisation were sought.

\subsubsection{Data Collection}

In Part A of the questionnaire, participants were asked 
to complete a short demographic questionnaire assessing the gender, race/ethnicity, English Grade in SPM and current living address. Through the living addresses, the socio-economic backgrounds of these students were identified by entering their data in the Population and Housing Census of Malaysia 2020 database portal. These students were then classified as rural and urban.

Meanwhile, the MIPQ III of Part B was specifically adopted to suit the need of answering the first research question of this study. Multiple Intelligences Profiling Questionnaire III or MIPQ III is the latest six-point Likert scale self-rating questionnaire that is based on Howard Gardner's Multiple Intelligence (MI) theory. It was profoundly developed and refined by Kirsi Tirri and Petri Nokelainen in 2007 with the addition of the ninth dimension of intelligences compared to the first and second versions with only seven and eight intelligence dimensions [21]. This inventory contains 35 items, aimed to identify the students' predominant intelligence. Each participant's answers to each items in the MIPQ III were logged into the Statistical Package for the Social Sciences (SPSS) version 21.0 to generate the most significant intelligence of the rural and urban groups.

The English proficiency levels of the two groups were measured through the performance in the writing test. To measure interrater reliability of the assessment, those writing papers were marked by two examiners who have years of experience in teaching and marking Malaysian University English Test (MUET) Paper 800/4 Writing. Each of the appointed examiners was given three weeks to mark the papers. They were given guidelines and briefed by the researchers on the Six-Trait Analytic Writing Rubric: Ideas, Organization, Voice, Word Choice, Sentence Fluency and Conventions to mark the papers. Each trait has a score of 1 to $6 ; 1$ is the lowest and 6 is the highest. The summed-up score of this composition is 36 . The marking process roughly took seven weeks to be completed and the marks were logged into the SPSS system.

All of the research instruments were collected in the same week; only the writing papers were sent to the examiners to be marked while the questionnaire remained to be analysed. However, statistical analyses could only be performed on the data once the two examiners had done with the marking process. An Independent Sample t-test was conducted on these data to (i) identify the predominant intelligence and (ii) investigate the disparity in the English language performances of rural and urban groups.

\section{Results}

\subsection{Research Objective 1}

To identify the predominant intelligence of the urban and rural pre-university students at a public university in

\section{Malaysia.}

Question 4 of the students' demographic information was gathered and analysed by entering the data on the Population and Housing Census of Malaysia 2020 database at https://ecensus.mycensus.gov.my/landing. The students' backgrounds were deemed as rural and urban based on the population of the districts of the states which they reside in. Of the 60 respondents who completed the questionnaire, well over half of those (40 respondents) were from urban areas, which topped at 66.67 percent. The remaining number of respondents (33.33 percent) were from the rural areas. All of the respondents who completed the questionnaire were from ten states of Peninsular Malaysia; Kedah, Johor, Melaka, Pahang, Pulau Pinang, Selangor, Federal Territory of Kuala Lumpur, Kelantan, Negeri Sembilan, Perak, and the other states of East Malaysia; Sabah, Sarawak, and Federal Territory of Labuan.

To identify the students' predominant intelligences, the six-point Likert scale of MIPQ III data was analysed using an Independent Sample t-test. This statistical analysis was conducted to identify each of the group's significant domain and to observe the comparison between the means of the two groups by each intelligence. Many experts have contended that Likert scale is interval, thus considering the mean score for the scale items is acceptably close to "the truth" when analysing Likert scale responses. The comparisons between the two groups are presented in Table 1 below:

Table 1. The Mean Scores Differences of Multiple Intelligences

\begin{tabular}{|c|c|c|c|}
\hline Intelligences & Location & N & Mean \\
\hline \multirow{2}{*}{ Verbal-Linguistic } & Rural & 20 & 4.0625 \\
\cline { 2 - 4 } & Urban & 40 & 4.0063 \\
\hline \multirow{2}{*}{ Logical-Mathematical } & Rural & 20 & 3.9875 \\
\cline { 2 - 4 } & Urban & 40 & 4.2000 \\
\hline \multirow{2}{*}{ Visual-Spatial } & Rural & 20 & 3.6875 \\
\cline { 2 - 4 } & Urban & 40 & 4.2375 \\
\hline \multirow{2}{*}{ Bodily-Kinesthetic } & Rural & 20 & 3.5750 \\
\cline { 2 - 4 } & Urban & 40 & 3.7875 \\
\hline \multirow{2}{*}{ Musical } & Rural & 20 & 3.7500 \\
\cline { 2 - 4 } & Urban & 40 & 3.8688 \\
\hline \multirow{2}{*}{ Interpersonal } & Rural & 20 & 5.5000 \\
\cline { 2 - 4 } & Urban & 40 & 4.0813 \\
\hline \multirow{2}{*}{ Intrapersonal } & Rural & 20 & 4.2000 \\
\cline { 2 - 4 } & Urban & 40 & 4.4250 \\
\hline \multirow{2}{*}{ Spiritual } & Rural & 20 & 4.4250 \\
\cline { 2 - 4 } & Urban & 40 & 4.6938 \\
\hline \multirow{2}{*}{ Environment } & Rural & 20 & 4.8825 \\
\cline { 2 - 4 } & Urban & 40 & 5.3003 \\
\hline \multirow{2}{*}{. } & & \\
\hline
\end{tabular}

The differences between the means of the two groups were further analyzed on each of the nine types of 
intelligence by considering its significance level (Sig. 2 tailed). As can be seen from Table 2, it shows that the $p$-values (2-tailed) of Visual-Spatial, Interpersonal, and Environmental intelligences are lesser than the required cut-off $(p=.05)$. The magnitude of the differences in the mean scores of these three intelligences was found to be $0.024,0.000$, and 0.044 respectively. This analysis reveals that through the scores of the domains obtained, it is apparent that the urban and rural students show significant differences in Visual-Spatial, Interpersonal, and Environmental intelligences. Table 1 also indicates that the urban students seem to be more inclined towards Visual-Spatial and Environment intelligences while the rural students show dominancy in Interpersonal intelligence.

Table 2. The $p$-values of Each Intelligences for Urban and Rural Groups

\begin{tabular}{|c|c|}
\hline \multirow{2}{*}{ Independent Samples Test } \\
\hline & t-test for Equality of Means \\
\cline { 2 - 2 } & Sig. (2-tailed) \\
\hline Verbal-Linguistic & 0.813 \\
\hline Logical-Mathematical & 0.217 \\
\hline Visual-Spatial & 0.024 \\
\hline Bodily-Kinesthetic & 0.314 \\
\hline Musical & 0.692 \\
\hline Interpersonal & 0.000 \\
\hline Intrapersonal & 0.279 \\
\hline Spiritual & 0.207 \\
\hline Environment & 0.044 \\
\hline
\end{tabular}

$\mathrm{p}<0.05=$ has difference; $\mathrm{p}<0.05=$ has no difference

Although the urban students were inclined towards Visual-Spatial and Environment intelligences, the magnitude of the mean score recorded in Environment is bigger than the other at 5.3003 (see Table 1), thus indicates that the urban students were superior in Environmental intelligence. Rural students, on the other hand, displayed stronger Interpersonal intelligence with the mean score of 5.5000, thus achieve the objective of this research.

\subsection{Research Objective 2}

To analyse the disparity of English writing performance between the urban and rural pre-university students at a public university in Malaysia.

Since the students were sorted into groups of urban and rural, the relationship between the socio-economic backgrounds of these pre-university students and their level of English proficiencies could be identified. The data were collected in pursuit to find out whether the urban students perform better in the writing skills than the students living in the rural areas. The scores obtained in the Malaysian University English Test (MUET) March 2016 Writing 800/4 Question 2 (Extended Writing) by the two groups were further analyzed by another Independent Sample t-test to find out whether there is a significant difference between the two socio-economic backgrounds and their ESL proficiencies. The result of this statistical analysis is presented in the Table 3 below.

Table 3. The Mean and $p$-value of the Writing Scores between Urban and Rural Students

\begin{tabular}{|c|c|c|c|c|}
\hline \multirow{4}{*}{$\begin{array}{l}\text { Writing Scores of } \\
\text { Malaysian } \\
\text { University English } \\
\text { Test (MUET) } \\
\text { March } 2016 \\
\text { Writing } 800 / 4 \\
\text { Question 2 }\end{array}$} & \multicolumn{4}{|c|}{ Independent Samples Test } \\
\hline & Location & $\mathbf{N}$ & Mean & $\begin{array}{c}\text { t-test for } \\
\text { Equality of } \\
\text { Means Sig. } \\
\text { (2-tailed) }\end{array}$ \\
\hline & Rural & 20 & 22.1000 & \multirow{2}{*}{0.009} \\
\hline & Urban & 40 & 26.1250 & \\
\hline
\end{tabular}

In the data presented in Table 3, the comparison between the means of the two groups demonstrates that there is a statistically difference in the writing scores, with means of 26.1250 by the urban respondents while only 22.1000 recorded by their rural counterpart. With the urban's mean score higher than the rural's, it reveals that the urban student did perform better in the writing test compared to the other group.

To find whether there is a significant difference between these two categories of students (urban and rural), the data for $p$-values (two-tailed) were considered. In the data presented in Table 3, the $p$-value ( 2 tailed) for the writing scores was lesser than the required cut-off of .05 $(p<.05)$. This finding shows that there is a statistically significant difference in the mean of the writing scores with 0.009 between the urban and rural pre-university students. This finding strongly suggests that the urban respondents performed better in the writing test compared to the rural, thus further indicates that the pre-university students from the urban backgrounds have better English proficiency levels than the ones from rural areas.

\section{Discussion}

To summarize, with regards to the differences of intelligences between the urban and rural groups, the findings reveal that the rural students have higher Interpersonal intelligences. Thus, it would seem that these students may be more interpersonally intelligent than their more proficient counterparts. Previous research finding also revealed that the rural students rated themselves higher than the urban students in term of Interpersonal intelligence [17]. A possible explanation for this might be due to the opportunities, activities, and environment available for the development of this intelligence. Students in the rural areas may be exposed to more activities with group interaction due to lack of adequate materials for teaching in the classroom, thus facilitating to the development of Interpersonal intelligence [6]. In addition, rural students are more exposed to activities outside the classroom 
environment, such as ploughing and harvesting, cutting trees, and many other tasks of household. They play different games because they have much time and enough space [17]. These activities facilitate to more interaction between them and it appears beneficial for the improvement of this domain. However, frequent social interaction using the students' mother tongue would not promote literacy in English language. Lack of opportunities to converse in English in and outside the classroom could explain the poor performance in the writing test compared to the students in the urban areas.

Interestingly, the urban students displayed stronger in Environmental intelligence. Contrary to the expectation, it seems that the urban students have started to appreciate nature and to be more environmentally sensitive. This result may partly be explained by the government's aspiration to be environmentally-conscious in its initiative of introducing Environmental Environment Program (EEP) across curriculum at primary and secondary levels. The formulation and introduction of Education for Sustainable Development in Malaysia's National Curriculum in 2017 aims to educate younger generation to appreciate the need to preserve environmental resources and create environmental awareness [5]. An increase in the understanding and awareness of the environment has led to the development of this intelligence among them. The students from the urban areas also displayed stronger Visual-Spatial intelligence. Better teaching facilities with the integration of technology in the urban areas could have affected the development of this domain. Recorded live lectures, video presentation, or online assignments stimulate student interest into visuals, providing an interesting opportunity to elevate their academic success, especially in language.

Regarding the writing proficiency level of the English language between the students in urban and rural areas, the finding clearly demonstrates a significant difference between the urban group and the higher writing scores through the writing assessment. This is not surprising as the statistics show that majority of the high proficient students are from the urban group. This may be attributed by the fact that urban students have adequate exposure to the language itself as well as sufficient practice of English language [11]. Also, the students' socio-economic backgrounds somewhat influence the acquisition in English. Most of the students in the rural areas come from the low-income families, thus getting the access to education resources and facilities is limited for them resulting in the poor performance in English [6]. In addition, attitudes in learning the language are shaped by the immediate surroundings, such as parents and peers [20]. Uncooperative environment to practice English may contribute to the students' poor performance, as parental participation and cooperation in their children's educational experiences seem to be lacking in rural areas [16].

\section{Conclusions}

Identifying the students' intelligences is crucial for the educators to understand the differences in their students' learning styles, so that they can implement best teaching strategies for them to learn English more effectively. More importantly, this study helps the educators to acknowledge the students' differences and start to redesign the lesson plans by incorporating different intelligences in a single lesson to improve the students' language skills.

Although the theory of MI has received a great deal of interest worldwide, transforming the present instructional practice by incorporating Multiple Intelligence into the existing lessons seems a great deal because it requires efforts and time. Undeniably, there are teachers who are interested or have been instinctively catering to different intelligences without even knowing of the Multiple Intelligences model [14], but due to lack of exposure and continuous training provided to assist them in implementing this theory, they have uncertainty in modifying the instructional practice with the MI. Designing the lessons to cater to different intelligences seems a great deal for teachers in rural areas because they do not get necessary educational support as it is difficult to get access to teaching aids such as CD's, computers, and projectors. This poor learning conditions may kill their creativity in designing the lesson, thus affecting the students' motivations to learn the language. If it is being implemented in the system, it brings benefits to the language learning.

The author believes that in order to improve English proficiency among the students, especially the rural students, it takes concentrated effort and cooperation from principals, teachers, and other stakeholders, including state and district officials. It is a high time for the top-down policy makers to reintroduce this theory into the existing curriculum by catering more intelligences as this theory could develop the domains the students are weak in, as well as strengthen the intelligence which students already major in. If Multiple Intelligences theory needs to be re-introduced into the curriculum, it needs to be refined and continuous training needs to be provided to the teachers to encourage them in adopting this theory in the classroom. This effort needs to be supported by higher ups, only if we aspire to achieve the Ministry's vision in shaping the students into holistic individuals.

\section{Acknowledgements}

I would like to thank Dr. Asmaa AlSaqqaf and Associate Professor Dr. Wardatul Akmam Din who have given me invaluable assistance and guidance. I would not have completed this journey without your assistance; the countless emails and meetings it took to put this together. I appreciate the constant encouragement and constructive feedback you have invested in me into producing this 
article.

\section{REFERENCES}

[1] Eng, L. L., \& Mustapha, G. (2010). Enhancing writing ability through multiple-intelligence strategies. Pertanika Journal of Social Science and Humanities, 18(SPEC. ISSUE), 53-63.

[2] Feng, A., \& Adamson, B. (2019). Language Policies in Education in the People's Republic of China. In A. Kirkpatrick \& A. J. Liddicoat (Eds.), The Routledge International Handbook of Language Education Plicy in Asia (p. 53). Routledge.

[3] Gobel, P., Thang, S. M., Sidhu, G. K., Oon, S. I., \& Chan, Y. F. (2013). Attributions to Success and Failure in English Language Learning: A Comparative Study of Urban and Rural Undergraduates in Malaysia. Asian Social Science, 9(2), 53-62. https://doi.org/10.5539/ass.v9n2p53

[4] Gurcay, D., \& Ferah, H. O. (2017). The Effects of Multiple Intelligences Based Instruction on Students' Physics Achievement and Attitudes. Jurnal of Baltic Science Education, 16(5), 666-678.

[5] Hanifah, M., Shaharudin, I., Mohmadisa, H., Nasir, N., \& Yazid, S. (2015). Riview of International Geographical Education Online. Transforming Sustainability Development Education in Malaysian Schools through Greening Activities, 5(1), 5-8.

[6] Hossain, M. (2016). English Language Teaching in Rural Areas: A Scenario and Problems and Prospects in Context of Bangladesh. Advances in Language and Literary Studies, 7(3). https://doi.org/10.7575/aiac.alls.v.7n.3p.1

[7] Ismail, N., Hussin, S., \& Darus, S. (2012). ESL Tertiary Students' Writing Problems and Needs: Suggested Elements for an Additional Online Writing Program (IQ-Write) for the BEL 311 Course. The International Journal of Learning, 18(9), 69-80. https://doi.org/10.18848/1447-9494/CGP/v18 i09/47748

[8] Jalaluddin, I., Md. Yunus, M., \& Yamat, H. (2011). Improving Malaysian rural learners' writing skill: A case study. Procedia - Social and Behavioral Sciences, 15, 18451851. https://doi.org/10.1016/j.sbspro.2011.04.013

[9] Jeffrey, S. (2019). Sabah Rural Students Outperform Urban Peers. Daily Express.http://www.dailyexpress.com.my/new s/132404/sabah-rural-students-outperform-urban-peers/

[10] Lawrence, A. S. A. (2014). Multiple Intelligence of Prospective Teachers. International Educational E-Journal, $3(2), 112-118$

[11] Ler, E. C. (2012). Cultural Factors Affecting English Proficiency in Rural Areas. Advances in Language and Literary Studies, 3(1), 1-23. https://doi.org/10.7575/aiac.all s.v.3n.1p.1
[12] Ming Foong, L., Shariffudin, R. S., \& Mislan, N. (2012) Pattern and Relationship Between Multiple Intelligences, Personality, Traits, and Critical Thinking Skills Among High Achievers in Malaysia. 3rd International Conference on E-Education, e-Business, e-Management, and e-Learning, 205-209.

http://eprints.uthm.edu.my/2353/1/rp040_IC4E_2012-F100 34.pdf

[13] Mohamed Radhi, N. A. (2019). Call for Comprehensive Study Into Decline in English Proficiency Among Students. New Straits Times. https://www.nst.com.my/news/nation/20 19/05/489779/call-comprehensive-study-decline-english-pr oficiency-among-students-nstty

[14] Pishghadam, R., Hashemi, M. R., \& Kermanshahi, P. N. (2011). Journal of Language Teaching and Research. 2(5).

[15] Sani, R. (2015). All-Round Concerted Effort Needed. New Straits Times. https://www.nst.com.my/news/2015/12/1174 41/all-round-concerted-efforts-

[16] Semke, C. a., \& Sheridan, S. M. (2011). Family-school connections in rural educational settings: A systematic review of the empirical literature. National Center for Research on Rural Education, 22(1), 1-29.

[17] Shahzada, G., Khan, U. A., Noor, A., \& Rahman, S. (2014). Self-Estimated Multiple Intelligences of Urban \& Rural Students. Journal of Research \& Reflections in Education (JRRE), 8(2), 116-124. http://search.ebscohost.com/login.a spx?direct=true $\& \mathrm{db}=$ ehh $\& A N=100362440 \&$ site $=$ ehost-live $\&$ scope $=$ site

[18] Swaran Singh, C. K., Jageer Singh, A. K., Abd Razak, N. Q., \& Ravinthar, T. (2017). Grammar Errors Made by ESL Tertiary Students in Writing. English Language Teaching, 10(5), 16-27. https://doi.org/10.5539/elt.v10n5p16

[19] Talif, of the Achievement and the Proficiency Levels in English as a Second Language Among Learners in Selected Rural and Urban Schools in Peninsular Malaysia. The English Teacher, $X I X($ July), 10.http://www.melta.org.my/journals/index.php/ tet/article/view/475/295

[20] Terrell, T. D., \& Brown, H. D. (2000). Principles of Language Learning and Teaching. In Language (Vol. 57, Issue 3). https://doi.org/10.2307/414380

[21] Tirri, K., \& Petri, N. (2008). Identification of Multiple Intelligences With The Multiple Intelligence Profiling Questionnaire III. Psychology Science Quarterly, 50(2), 206-221.

[22] Vries, M. De. (2014). The Role of the Foundation Phase Teacher in Facilitating Multiple Intelligences in the Classroom (Issue July). http://www.dailyexpress.com.my/n ews/132404/sabah-rural-students-outperform-urban-peers/

[23] Zulkefly, F., \& Razali, A. B. (2019). Malaysian Rural Secondary School Students' Attitudes Towards Learning English as a Second Language. International Journal of Instruction, 12(1), 1141-1156.https://doi.org/10.29333/iji.2 $019.12173 \mathrm{a}$ 